\title{
Assessment Indicators as a Tool of Process Monitoring, Benchmarking and Learning Outcomes Assessment: Features of Two Types Indicators
}

\author{
Soichiro Aihara *
}

\begin{abstract}
This study proposes two types of basic assessment indicators named the JCIRP assessment indicators and shows these features. These indicators are a tool of process monitoring, benchmarking and learning outcomes assessment to improve undergraduate education. These indicators are based on the comprehensive I-E-O model and the involvement theory. One type of indicators are made in accordance with the same procedure of the CIRP constructs by the HERI at the UCLA. The other are made with the same scoring procedure of the Engagement Indicators by the Center for Postsecondary Research at the Indiana Univ. School of Education. Each type of indicators have their own features. The Japanese higher education system is under the requirement for qualitative transformation of undergraduate education, the JCIRP assessment indicators will be one of the useful tool to guide education practice.
\end{abstract}

Keywords: Assessment Indicator, I-E-O model, Involvement Theory, Student Engagement

\section{Introduction}

This study is an applied study that connects theoretical studies of the higher education to the practice of education and management at colleges and universities. The purpose of this study is to make two types of assessment indicators from student survey and to show these distinctive features. In August 2012 in Japan, the Central Council for Education published a report that requires qualitative transformation of the undergraduate education using the assessment methods such as standard tests, rubrics, learning portfolios and so on [1]. Student survey also contributes that requirements by the assessment indicators as a tool of process monitoring, benchmarking, and learning outcomes assessment.

In the United States where the learning assessment at higher education is prosperous, Astin (1991) points out that many of those assessment activities were ineffective [2]. Assessment activities are effective only when we conform to "Principles of Good Practice for Assessing Student Learning” [3] and assessment indicators can guide the education practice. This applied study proposes assessment indicators for the Japanese Cooperative Institutional Research Pro-

\footnotetext{
* Aichi University of Education, Aichi, Japan
} 
gram (JCIRP) as the tool of process monitoring, benchmarking, and learning outcomes assessment. These called as the JCIRP assessment indicators. They make broaden the horizons of assessment activities. Kaneko have mentioned these necessities about process monitoring using student survey [4]. The assessment indicators of student survey can bring us the integrated vision.

The theoretical background of this study is the I-E-O model and the involvement theory by Astin [5]. The I-E-O model can make us recognize students' diverse background, learning environment, learning process and student learning outcomes in an integrated scheme. The involvement theory means that student involvement or student engagement is determinants factor of students learning outcomes. To improve undergraduate education, we need to arrange assessment indicators according to the I-E-O model and the involvement theory, then colleges and universities should deploy their resources to gain student involvement or student engagement. There are two points before to make assessment indicators from student survey.

First point is elaboration and expansion of the I-E-O model and the involvement theory. The I-E-O model and the involvement theory have strong robustness and it is enough to direct the study. We need, however to elaborate and expand them to construct the framework of the JCIRP assessment indicators. Because in the Japanese higher education scene, there are requirements for active learners, active learnings and secure the learning-and-study time (Gakusyu Jikan in Japanese). These requirements need the psychological domain inside the I-E-O model and the involvement theory to incorporate these concepts such as identity, a sense of belonging, learning strategy and so on. Depending the recent precedent studies of Kuh, Pascarella, Terenzini and Hurtado, this study adopt the comprehensive I-E-O model that model expands through incorporating psychological perspective of student engagement [6].

Second point is how to create assessment indicators. One purpose of this study is to show the features two types of assessment indicators. The most famous indicators made from student survey is the NSSE benchmarks or the Engagement Indicators. They are made from the National Survey of Student Engagement (NSSE). The CIRP constructs is also famous indicators which are made from the Cooperative Institutional Research Program (CIRP). These student survey are not only the national representing surveys in the U.S. but also de facto global standards student surveys. Survey items of the JCIRP are made with maintaining compatible the items of the CIRP. Then in this study, first of all, in accordance with the same statistical procedure of the CIRP constructs [7] [8], the JCIRP assessment indicators are made so that compatible with the CIRP constructs. The technical detail of this procedure and statistical values are shown in the paper [9]. One feature of the CIRP constructs is that they are made of deviation value. After that the NSSE type of assessment indicators are made in accordance with the same scoring procedure of the Engagement Indicators [10]. One feature of the NSSE type of assessments indicators is that they are made of mean value. This study show their features from the comparison of two types assessment indicators.

Thus this study creates the JCIRP assessment indicators based on (1) the comprehensive I-E-O model, (2) the involvement theory, and show the features two types of assessments indicators. One is (3) the CIRP constructs type that are made of deviation value. The other one is (4) the Engagement Indicators of the NSSE type that are made of mean value. From comparison of two indicators: the CIRP constructs type and NSSE Engagement Indicators type, we can find out the features of these indicators. 


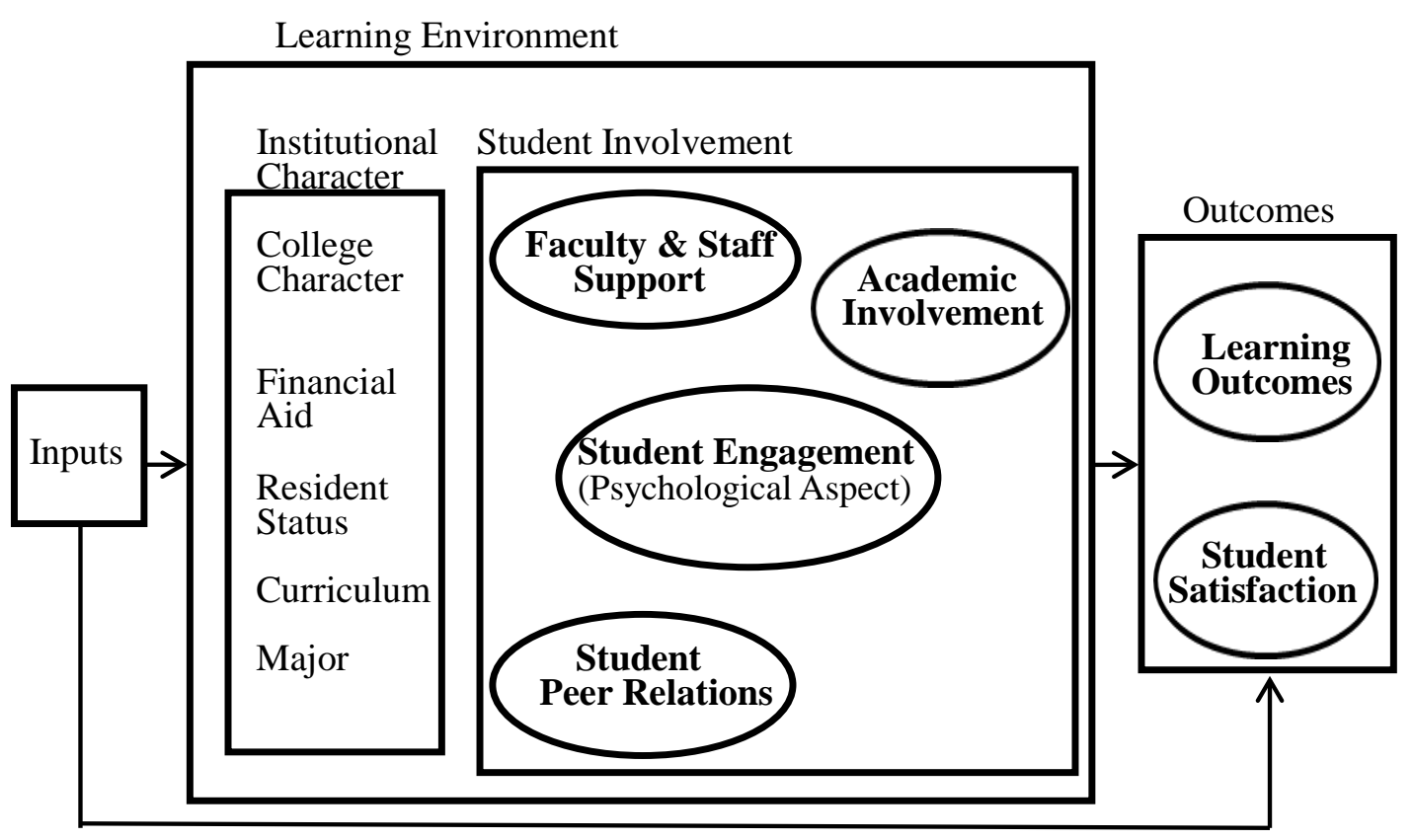

Figure 1: Comprehensive Conceptual Framework for the JCIRP

\section{Framework of JCIRP Assessment Indicators and Data}

\subsection{Framework}

Figure 1 is the framework developed for the JCIRP assessment indicators. This framework is the comprehensive I-E-O model which elaborate and expand the I-E-O model and the involvement theory through incorporating the framework of Terenzini and Reason [11]. The feature point of this model is "Student Engagement" locates at the center of the student involvement. It should pay attention however, this domain is alternative engagement that focuses on the psychological aspect of student engagement. Brief illustrations are as follows.

(1)Inputs: There are items of precollege information such as personal attribute (gender, age, first generation, and international student), secondary education (high school grade, control type, coeducation, and high school experience), college choice (reason of college attendance, aspiration, decision making period, and admission type) and so on. Paying attention to precollege information of students, colleges and universities can deploy their resources and improve their learning environment such as to reduce the educational inequality. Because the focus of this study is to show the features of two types of assessment indicators, this study doesn't refer so much to this precollege information area.

(2)Learning Environment: Astin (1993) divided environment area into eight domains: (a) characteristics of institutions, (b) financial aid, (c) residence, (d) curriculum, (e) major, (f) faculty, (g) peer group, and (h) student involvement (p.32) [10]. In this framework, through (a) to (e) are reconstructed as institutional character domain and through (f) to (h) are reconstructed as student involvement domain. Astin divided further the student involvement domain into five subdomains: academic involvement, involvement with faculty, involve- 
ment with student peers, involvement in work, and other forms of involvement (p.71). In this framework, involvement in work and other forms of involvement are merged to the Academic Involvement domain. There are three reasons. First, adult students aren't much in the higher education in Japan. Second, there is an item to measure the working hours as part time job. Third, in the Academic Involvement domain, there is the disengagement indicator as the reverse indicator to academic involvement.

Furthermore in order to emphasize support, this study recategorizes involvement with faculty as faculty \& staff support, and in order to emphasize relations among students this study recategorizes involvement with student peers as student peer relations. In the center of student involvement, the Student Engagement domain added newly. This domain means psychological aspect of student engagement, in other words, cognitive and emotional involvement of student, such as learning motivation, self-regulation, and identities of students. Sense of belonging is also included in this domain. They are seemed to outcomes after entrance, however according to Astin (1993), they are treatable as intermediate outcomes.

(3)Learning Outcomes and Student Satisfaction: There are various kinds of elements as outcomes, but this study restrict to uses only five outcome indicators. There are two outcome domains. These are the Learning Outcomes and the Student Satisfaction. In this study, the Learning Outcomes domain means gains of knowledge and skills, human relations, and civic awareness from colleges and universities education. The Student Satisfaction domain means satisfaction with coursework and satisfaction with overall.

This study make 10 assessment indicators at the six domains which shown with oval and bold letters.

\subsection{Data}

The data is the Japanese Junior College Student Survey (JJCSS) which is one of the survey from the JCIRP. The JJCSS began cooperation with the Japan Association for College Accreditation (JACA) at 2008. The participants of colleges and students to the JJCSS are following: 2008 first survey is 9 colleges and 2,496 students; 2009 second survey is 30 colleges and 8,850 students; 2010 third survey is 23 colleges and 8,539 students; and 2011 fourth survey is 34 colleges and 9,637 students [12]. To make the JCIRP assessment indicators, this study use the data of 2009 second survey.

\section{JCIRP Assessment Indicators}

Table 1 shows the comparison of the CIRP constructs and the JCIRP assessment indicators. This study suppose that students learning process rely on the comprehensive I-E-O model and involvement theory. The learning environment consists of the Institutional Character domain and the Student Involvement domain, and outcomes area consist of the Learning Outcomes domain and the Student Satisfaction domain. The learning process in the Student Involvement domain, students receive (1) the Support form Faculty and Staff, build (2) the Student Peers Relations, and set their mind to (3) the Student Engagement which refers to psychological aspect of engagement. As of the Academic Involvement, there are positive behaviors (4) the Active Learning, and negative behaviors (5) the Academic Disengagement. As for the Learning Outcomes, there are (6) the Knowledge and Skills, (7) the Human Relations, and (8) the Civic Awareness. Finally this study assumes that satisfied students in (9) the Satisfaction with Coursework and (10) 
Table1: Comparison of the CIRP Constructs and the JCIRP Assessment Indicators

\begin{tabular}{|c|c|}
\hline CIRP Constructs: YFCY & JCIRP Assessment Indicators: JJCSS \\
\hline Student-Faculty Interaction [6] & $\begin{array}{l}\text { (1) Faculty and Staff Support } \\
1 \text { Advice and guidance about your educational program } \\
2 \text { Emotional support and encouragement } \\
3 \text { Help to improve your study skills } \\
4 \text { Intellectual challenge and stimulation } \\
5 \text { Help in achieving your professional goals } \\
\end{array}$ \\
\hline Sense of Belonging [4] & $\begin{array}{l}\text { (2) Student Peer Relations } \\
1 \text { Interaction with other students } \\
2 \text { Overall sense of community among students } \\
3 \text { Availability of campus social activities } \\
4 \text { Respect for the expression of diverse beliefs }\end{array}$ \\
\hline Academic Adjustment [5] & $\begin{array}{l}\text { (3) Student Engagement (Psychological Aspect) } \\
1 \text { Understand what your professors expect of you academically } \\
2 \text { Develop effective study skills } \\
3 \text { Adjust to the academic demands of college } \\
4 \text { Manage your time effectively } \\
\end{array}$ \\
\hline Habits of Mind [11] & $\begin{array}{l}\text { (4) Academic Involvement: 1)Active Learning } \\
1 \text { Took interdisciplinary courses } \\
2 \text { Worked on independent study } \\
3 \text { Discussed course content with students outside of class }\end{array}$ \\
\hline Academic Disengagement [5] & $\begin{array}{l}\text { (5) Academic Involvement: 2)Academic Disengagement } \\
1 \text { Failed to complete homework on time } \\
2 \text { Came late to class } \\
3 \text { Missed class due to part-time job or employment } \\
4 \text { Missed class for other reasons } \\
\end{array}$ \\
\hline $\begin{array}{c}\text { Academic Self-Concept [4] } \\
\text { Social Self-Concept [3] } \\
\text { Pluralistic Orientation [5] } \\
\text { Cross Racial Interaction-Positive [6] } \\
\text { Cross Racial Interaction-Negative [3] } \\
\text { Social Agency [6] } \\
\text { Leadership [5] } \\
\text { Civic Engagement [8] }\end{array}$ & $\begin{array}{l}\text { (6) Learning Outcomes: 1)Knowledge and Skills } \\
1 \text { General knowledge } \\
2 \text { Analytical reasoning or Problem-solving skills } \\
3 \text { Knowledge of a particular field or discipline } \\
4 \text { Critical thinking skills } \\
\text { (7) Learning Outcomes: 2)Human Relations } \\
1 \text { Leadership abilities } \\
2 \text { Interpersonal skills } \\
3 \text { Ability to get along with other people } \\
4 \text { Communication skills }\end{array}$ \\
\hline Civic Awareness [3] & $\begin{array}{l}\text { (8) Learning Outcomes: 3)Civic Awareness } \\
1 \text { Understanding of the problems facing your community } \\
2 \text { Understanding of national issues } \\
3 \text { Understanding of global issues } \\
\end{array}$ \\
\hline Satisfaction with Coursework [4] & $\begin{array}{l}\text { (9) Satisfaction with Coursework } \\
1 \text { General education or core curriculum courses } \\
2 \text { Courses in your major field } \\
3 \text { First-year programs(e.g., first-year seminar) } \\
4 \text { Overall quality of instruction } \\
5 \text { Relevance of coursework to everyday life } \\
6 \text { Relevance of coursework to future career plans } \\
7 \text { Class size } \\
\end{array}$ \\
\hline Satisfaction Overall [5] & $\begin{array}{l}\text { (10) Satisfaction Overall } \\
1 \text { Overall college experience } \\
2 \text { Are your college life fulfilling? } \\
3 \begin{array}{l}\text { If you could make your college choice over, would you still } \\
\text { choose to enroll at your current college? }\end{array} \\
\end{array}$ \\
\hline
\end{tabular}

Note : CIRP Constructs of YFCY obtained from the URL $<$ http://www.heri.ucla.edu/PDFs/CONSTRUCTS.DATA.pdf $>$. 
the Satisfaction overall.

The assessment items are displayed under each of the JCIRP assessment indicators. These are used to make the JCIRP assessment indicators. When their assessment items are quite the same with the CIRP constructs, these are surrounded with a solid line. If they are different, the CIRP constructs are surrounded with a dash line. For example, in the Civic Awareness domain "[3]" means the number of assessment items which used to make the CIRP construct. These three items are the same of right side of "(8)-1 Understanding of the problems facing your community,” “(8)-2 Understanding of national issues,” "(8)-3 Understanding of global issues.” Then these indicators are surrounded with a solid line. As for the Satisfaction with Coursework, the JCIRP assessment indicator uses 7 items whereas the CIRP constructs uses 4items. The JCIRP assessment indicator uses more 3 items which the CIPR constructs don't use. These indicators are quite the same, then these are surrounded with a solid line. The important difference between the CIRP constructs and the JCIRP assessment indicator are as follows. First there aren't indicators of the Sense of Belonging, the Habits of Mind, the Self-Concept and some other indicators in the JCIRP assessment indicators. These indicators, however are important, we might need to locate them within the framework. Second as to statistical criteria to make the Academic Involvement: 1) Active Learning, this assessment indicator in fact couldn't satisfy with the single factor criteria. It is important in the Japanese higher education to enhance the active learning. However, the questionnaire of JJCSS2009 hasn't enough items to make assessment indicators about active learning. It is necessary to add the items related to active learning.

\section{Two Types of Assessment Indicators: A Case Study}

The assessment unit of student survey is program or institution that is not individual student. Because of that we have to assess at the department level of junior college. This study compares the junior college students about the first-year students at the child education department of the OK junior college, the first-year students major in education, and all participant students. Name of the OK junior college is fictional. Figure 2 and Figure 3 show the two types of assessment indicators. Both are for the process monitoring, benchmarking, and learning outcomes assessment. Table 2 shows statistical value used Figure 2 and Figure 3. In Figures, circle markers show the score of first-year students at the child education department of the OK junior college. Square markers show the score of first-year students major in education and triangle markers show the score of all students of the JJCSS2009. The score of Figure 2 is deviation value and Figure 3 is mean value.

As to Figure 2 for example, the score of (1) Faculty and Staff Support is that first-year students of the department of child education at the OK Junior College 52.0 point, first-year students major in education 49.8 point, and all students of the JJCSS2009 50.0 point. It is obvious that students at the child education department of the OK junior college receive more careful support from faculty and staff than students major in education and all students of the JJCSS2009. Similarly the scores of the OK junior college are high at (2) Student Peer Relations (52.2), (4) Academic Involvement: 1) (5) Active Learning (55.5), 2) Academic Disengagement (52.2), (9) Satisfaction with Coursework (52.4), and (10) Satisfaction Overall (51.3). It means that students at the child education department of the OK junior college have good relations with peers, learning 


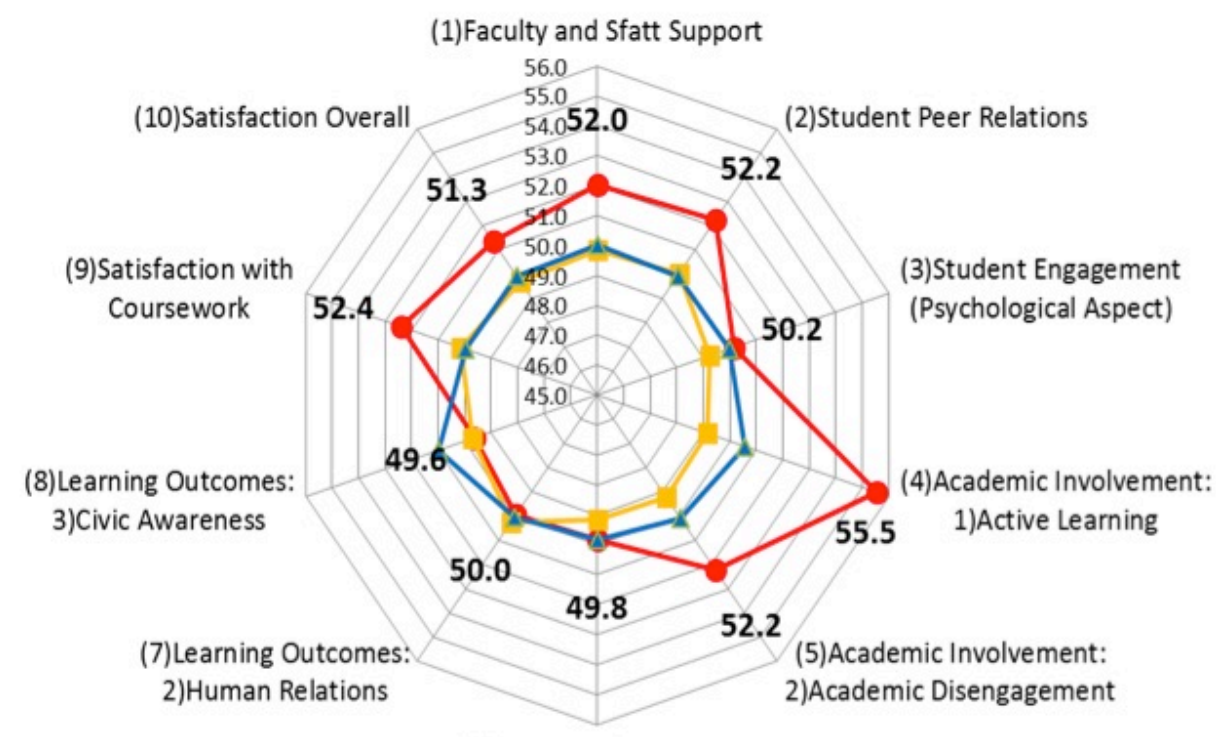

(6)Learning Outcomes:

1)Knowledge and Skills

-OK JC. Dept. of Child Edu. 1yr

- JuCSS2009 Education Major 1yr

$-1-J \operatorname{JCSS} 2009$ All

Figure 2: Cobweb Chart of the JCIRP Assessment Indicators

(CIRP constructs type: deviation value)

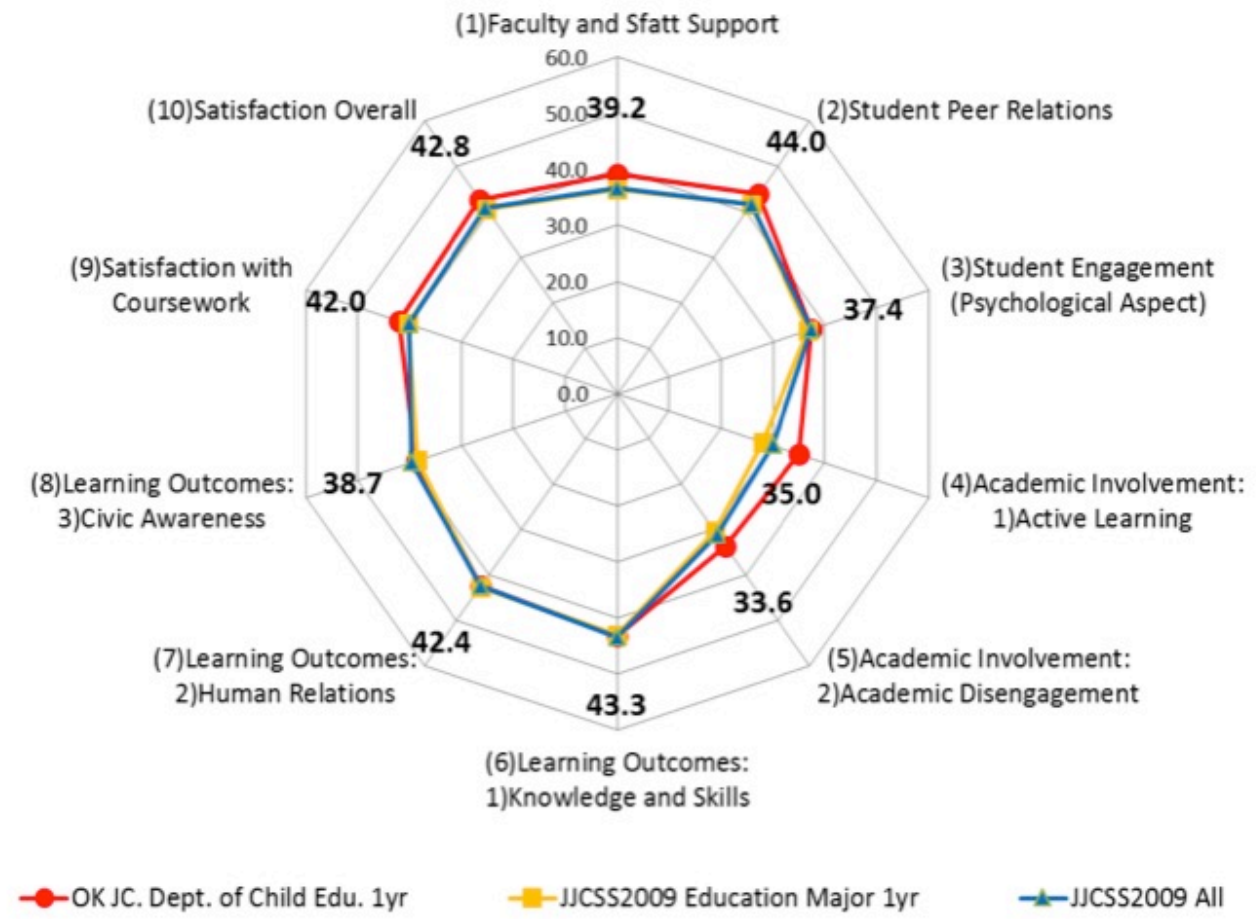

Figure 3: Cobweb Chart of the JCIRP Assessment Indicators

(NSSE Engagement Indicators type: mean value) 
Table2: The JCIRP Assessment Indicators of First Year Students of Education Major and Child Edu. Dept. of the OK JC., and JJCSS2009 All, (mean value: deviation value)

\begin{tabular}{|c|c|c|c|c|c|c|}
\hline & \multicolumn{4}{|c|}{ First Year Students } & \multirow{2}{*}{\multicolumn{2}{|c|}{ JJCSS2009 All }} \\
\hline & \multicolumn{2}{|c|}{$\begin{array}{c}\begin{array}{c}\text { Child Edu. Dept. of } \\
\text { the OK JC. }\end{array} \\
\end{array}$} & \multicolumn{2}{|c|}{ Education Major } & & \\
\hline & $\begin{array}{l}\text { mean } \\
\text { value }\end{array}$ & $\begin{array}{c}\text { deviation } \\
\text { value }\end{array}$ & $\begin{array}{l}\text { mean } \\
\text { value }\end{array}$ & $\begin{array}{c}\text { deviation } \\
\text { value }\end{array}$ & $\begin{array}{l}\text { mean } \\
\text { value }\end{array}$ & $\begin{array}{c}\text { deviation } \\
\text { value }\end{array}$ \\
\hline (1)Faculty and Sfatt Support & 39.2 & 52.0 & 36.6 & 49.8 & 36.6 & 50.0 \\
\hline (2)Student Peer Relations & 44.0 & 52.2 & 41.8 & 50.0 & 41.8 & 49.9 \\
\hline $\begin{array}{l}\text { (3)Student Engagement } \\
\text { (Psychological Aspect) }\end{array}$ & 37.4 & 50.2 & 36.6 & 49.3 & 37.3 & 50.0 \\
\hline $\begin{array}{l}\text { (4)Academic Involvement: } \\
\text { 1)Active Learning }\end{array}$ & 35.0 & 55.5 & 28.0 & 49.2 & 29.9 & 50.6 \\
\hline $\begin{array}{l}\text { (5)Academic Involvement: } \\
\text { 2)Academic Disengagement }\end{array}$ & 33.6 & 52.2 & 30.2 & 49.2 & 31.2 & 50.1 \\
\hline $\begin{array}{l}\text { (6)Learning Outcomes: } \\
\text { 1)Knowledge and Skills }\end{array}$ & 43.3 & 49.8 & 43.1 & 49.2 & 43.4 & 49.8 \\
\hline $\begin{array}{l}\text { (7)Learning Outcomes: } \\
\text { 2)Human Relations } \\
\end{array}$ & 42.4 & 50.0 & 42.6 & 50.2 & 42.4 & 50.0 \\
\hline $\begin{array}{l}\text { (8)Learning Outcomes: } \\
\text { 3)Civic Awareness }\end{array}$ & 38.7 & 49.6 & 38.5 & 49.7 & 39.7 & 51.0 \\
\hline (9)Satisfaction with Coursework & 42.0 & 52.4 & 40.4 & 50.2 & 40.2 & 50.0 \\
\hline (10)Satisfaction Overall & 42.8 & 51.3 & 40.8 & 49.7 & 41.0 & 49.9 \\
\hline
\end{tabular}

Source: Author made.

actively and satisfy with coursework and college. The score of (4) Active Learning (55.5) display the distinctive feature of this department. The sore of (5) Academic Disengagement (52.2), however is also high. This score is negative value that means there are many students of lateness and absence at classes of the OK junior college. It also suggests that there are many students who cannot submit their homework on time. As to (3) Student Engagement (50.2), (6) Learning Outcomes: 1) Knowledge and Skills (49.8), (7) 2) Human Relations (50.0), (8) 3) Civic Awareness (49.6) are nearly the same score with the first-year students of education major and all students of the JJCSS2009. The challenges of this department is to form a learning habit and to increase the learning outcomes such as basic knowledge, skills, and human relations.

Figure 3 shows us the same tendency. However, that tendency is not clear than in the Figure 2. What Figure 3 shows us distinctively is achievement level of each assessment indicators. For example in Figure 3, the score at the child education department of the OK junior college (4) Active Learning (35.0) and (5) Academic Disengagement (33.6) are lower than the scores of other metrics. The indicators of the CIRP constructs type which use deviation value is very effective to compare within the assessment indicators. These show relative position of the metrics. On the other hand, the indicators of the NSSE Engagement Indicators type which use mean value is very effective to compare between the assessment indicators. These show achievement level of the metrics. 


\section{Discussion and Conclusion}

This applied study showed that JCIRP assessment indicators are a useful tool for the process monitoring, benchmarking and learning outcomes assessment. If we based on the comprehensive I-E-O model and the involvement theory, assessment indicators can contribute to improve undergraduate education which are required qualitative transformation. Student survey is no less useful than other tools such as standard tests, rubrics, learning portfolios with respect to present objective evidences. Student survey can provide the integrated information about the process of learning. In addition, the cost is relatively inexpensive.

The purpose of this study is to make two types of assessment indicators from student survey and to show these distinctive features. One type of indicators are made in accordance with the same procedure of the CIRP constructs by the HERI at the UCLA. The other are made the same scoring procedure of the Engagement Indicators by the Center for Postsecondary Research at the Indiana Univ. School of Education. From the comparison of Figure 2 and Figure 3, it is clear that each type of indicators have their own features. The indicators of the CIRP constructs type which use deviation value is very effective to compare within the assessment indicators. These show relative position of the metrics. On the other hand, the indicators of the NSSE Engagement Indicators type which use mean value is very effective to compare between the assessment indicators. These show achievement level of the metrics. We will need to use both types of indicators depending on the purpose.

There are several points which need to study further. The first point is that this study presents only basic assessment indicators. It needs to enrich indicators more. Especially the JCIRP assessment indicator of (4) Academic Involvement: 1) Active Learning couldn’t satisfy enough with the statistical criteria. Active learning is important in the contemporary Japanese higher education, then we need to create items and add them to the questionnaire. As for the Sense of Belonging, the Habits of Mind, the Self-Concept and some other indicators, there aren't the JCIRP assessment indicators those are equivalent of the CIRP indicators. Because the questionnaire has no items about them, we should add them.

The second point is that improvement of undergraduate education can achieve only through educational practice by colleges and departments. The JCIRP assessment indicators can provide evidence and it may direct to the improvement, but taking the action is depending on their education policy and practice. It is necessity to supplement by the qualitative method such as focus group interview with students and discuss these information with faculty and staff. It will be faculty development and staff development.

Finally as to the student learning outcomes, this study presents only five outcomes indicators which are consist of learning outcomes and student satisfaction. There are the social demand of fostering global human resources, intercultural ability, generic skills, and something like. Considering them, we will need to make more assessment indicators which covered undergraduate education.

\section{Acknowledgement}

The author wish to thank JCIRP research group for their friendly support and the anonymous 
reviewers for their useful comments. This paper is what added and modified based on the presentations at the Second IIAI International Conference on Advanced Applied Informatics (2013). The author wish to thank for every comments from colleagues.

\section{References}

[1] Central Council for Education, Towards the Qualitative Transformation of University Education to Build a New Future: To the Colleges and Universities that Foster Strength to Learn throughout the Life and to Think Actively, Tokyo: Ministry of Education, Culture, Sports, Science \& Technology in Japan, 2012. [in Japanese].

[2] A.W. Astin, Assessment for Excellence: The Philosophy and Practice of Assessment and Evaluation in Higher Education. New York: Macmillan Publishing, 1991.

[3] American Association of Higher Education, "Principles of Good Practice for Assessing Student Learning," Washington, DC: American Association of Higher Education, 1992; http://www.learningoutcomeassessment.org/NILOAarchive.html.

[4] M. Kaneko, "Alternative Models for Relating Evaluation and Improvement: Standardized Outcome Assessment vs. Process Monitoring,” University Evaluation Review. no.8, 2009, pp.17-29. [in Japanese]

[5] A.W. Astin, What Matters in College?: Four Critical Years Revisited, San Francisco: Jossey-Bass, 1993, p.508.

[6] S. Aihara, "Development of Comprehensive I-E-O model Incorporating Alternative Engagement,” Proc. 2012 IIAI Int'l Conf. on Advanced Applied Informatics (IIAI-AAI 12). IEEE CS, 2012, pp.303-308; doi: 10.1109/IIAI-AAI.2012.66.

[7] J. Sharkness, L. DeAngelo, J. Pryor, CIRP Construct Technical Report. Higher Education Research Inst., Graduate School of Education \& Information Studies, Univ. of California, Los Angeles, 2010.

[8] J. Sharkness, L. DeAngelo, "Measuring Student Involvement: A Comparison of Classical Test Theory and Item Response Theory in the Construction of Scales from Student Surveys," Research in Higher Education, vol.52, no.5, 2011, pp.480-507.

[9] S. Aihara, "Learning Assessment of the Department of Child Education at Kun-ei Women's College: Creating Assessment Indicators from JJCSS2009,” Research Journal [Kenkyu Kiyou].vol.47, Osaka Kun-ei Women’s College, 2012, pp.1-10. [in Japanese]

[10] NSSE, Engagement Indicators; http://nsse.indiana.edu/html/engagement_indicators.cfm.

[11] P.T. Terenzini, and R. D. Reason, Parsing the First Year of College: A Conceptual Framework for Studying College Impacts. Paper presented at the annual meeting of the Association for the Study of Higher Education, 2005.

[12] Japan Association for College Accreditation (JACA), Tandaiseichosa; http://www.jaca.or.jp/service/other/research/tandaiseichosa.html 